\title{
Ratio as a tool of financial analysis for Indian Retail sector companies
}

\author{
Dr.Vani R Kamath ${ }^{1}$, Sharmila Kulkarni ${ }^{2}$ \\ 1(Department of Business Management, Padmashree Dr.D.Y.Patil University, Sector-4, CBD Belapur, Navi \\ Mumbai, India) \\ 2(Department of Business Management, Padmashree Dr.D.Y.Patil University, Sector-4, CBD Belapur, Navi \\ Mumbai, India)
}

\begin{abstract}
In financial management ratios act as a major tool for comparison of financial results. This research paper attempts to compare three retail giants of India listed with Bombay Stock Exchange. The study covers a period of one year i.e., 2011-12. The inter firm comparison also recommends the investors as well as the researchers to understand the liquidity, profitability, activity and capital structure position of the three retail companies. For the purpose of study, the ratios are selected randomly which would clearly demonstrate the results and the financial position of the company over a period of one year.
\end{abstract}

Keywords: Ratios, liquidity, capital structure, profitability.

\section{Introduction}

Indian retail industry has seen a major growth over the years. Foreign direct investment as well as the foreign institutional investors contribute major share for the business of these retail giants. The central government has approved 51\% FDI in multi brand retail in India which would boost the business of this sector further. With the advent of this news the retail sector companies are in the verge of showing good financial results in the near future.

The present study tries to cover financial results of three major retail outlets of India like Trent, Shoppers Stop and Provogue.

\section{Objectives Of The Study}

The research paper has the following objectives:

2.1 To calculate the liquidity, capital structure, profitability and activity ratios of the retail organisations

2.2 To distinguish between these three companies on the basis of financial performance.

2.3 To analyse the ratios on the basis of the results.

2.4 To guide the investors as well as the researchers for future investment.

\section{Research Methodology}

For the purpose of research, that secondary data has been used from the company websites. The research is more exploratory in nature. As all the three companies are listed with the Bombay Stock Exchange, the annual reports as well as the share price details were taken from this site. Three companies are taken as the sample size and the financial information was taken for the period of one financial year 2011-12. The three companies are then compared and the analysis was done by applying the tool of ratios.

The following formulas were used to calculate various ratios:

Liquidity Ratios:

Current Ratio $=$ Current Assets/ Current Liabilities.

Quick Ratio $=$ Current Assets- Inventory/ Current Liabilities.

Profitability Ratios:

Gross Profit Ratio= Gross Profit/Sales*100

Net Profit Ratio $=$ Net Profit/Sales*100

Earnings Per Share $=$ Net Profit After Tax/ Number of Equity Shares Outstanding

Price Earnings Ratio= Market price of the share as on 22-2-2013/ Earnings per Share

Capital Structure Ratio:

Debt Equity Ratio=Total Debt/ Net Worth

Activity Ratio:

Inventory Turnover Ratio $=$ Cost of Goods Sold $/$ Average Inventory

Debtors Turnover Ratio $=$ Sales/ Debtors +Bills Receivables

Assets Turnover Ratio $=$ Sales $/$ Total Assets 
Trent:

Trent is a retail operations company that owns and manages a number of retail chains in India. Established in 1998, Trent runs lifestyle chain Westside, one of India's largest and fastest growing chain of lifestyle retail stores, Star Bazaar, a hypermarket chain, Landmark, a books and music chain, and Fashion Yatra, a complete family fashion store. It has its headquarters in Mumbai.

Shoppers Stop is an Indian department store chain promoted by the K Raheja Corp Group (Chandru L Raheja Group), started in the year 1991 with its first store in Andheri,Mumbai. Shoppers Stop Ltd has been awarded "the Hall of Fame" and won "the Emerging Market Retailer of the Year Award", by World Retail Congress at Barcelona, on April 10, 2008. Shoppers Stop is listed on the BSE. In 2011, Shoppers Stop has 53 stores in India.

Provogue is a Mumbai based Indian company incorporated on November 11, 1997 as Acme Clothing Private Limited. The brand Provogue was launched in March 1998 and is currently one of the biggest retail apparel brands in India based in Mumbai. As of March 31, 2009, Provogue fashions and accessories were available across 126 Provogue stores and 110 shop-in shops

Major Financial Results of the companies for the year 2011-12:

\begin{tabular}{|l|l|l|l|}
\hline Particulars & $\begin{array}{l}\text { Trent } \\
\text { (Amount in Crores of } \\
\text { Rupees) }\end{array}$ & $\begin{array}{l}\text { Shopper's Stop } \\
\text { (Amount in Lacs of } \\
\text { Rupees) }\end{array}$ & $\begin{array}{l}\text { Provogue } \\
\text { (Amount in Lacs of } \\
\text { Rupees) }\end{array}$ \\
\hline Current Assets & 650.50 & 28180.96 & 52392 \\
\hline Current Liabilities & 197.20 & 56734.78 & 23112 \\
\hline $\begin{array}{l}\text { Quick Assets(Current } \\
\text { assets-Stock) }\end{array}$ & 471.27 & 6976.95 & 29923 \\
\hline Gross Profit & 582.02 & ------ & 20766 \\
\hline Sales & 1715.03 & ----- & 60959.14 \\
\hline Net Profit & 47.27 & 6426 & 1778.69 \\
\hline Profit After Tax & 47.27 & 6426 & 1778.69 \\
\hline Market Price of the share & 1111.40 & 425 & 12.75 \\
\hline Total Debt & 20.13 & 1916.92 & 35743.82 \\
\hline Networth & 1354.18 & 65850 & 55419 \\
\hline Opening inventory & 1.91 & 15114 & 31893 \\
\hline Closing inventory & 0.97 & 21204 & 22469 \\
\hline Debtors & 18.36 & ---- & 15143 \\
\hline Debtors No.of days & & 3 & 153394 \\
\hline Total Assets & 2014.43 & 126289.65 & \\
\hline
\end{tabular}

Source:BSE India

IV. Results and Ranks:

\begin{tabular}{|l|l|l|l|}
\hline Ratios & Trent & Shoppers Stop & Provogue \\
\hline Current Ratio & 3.298 & 0.496 & 2.267 \\
\hline Rank & 2 & 3 & 1 \\
\hline Quick Ratio & 2.389 & 0.123 & 1.29 \\
\hline Rank & 2 & 3 & 1 \\
\hline Gross Profit Ratio & $33 \%$ & $32.70 \%$ & $34 \%$ \\
\hline Rank & 2 & 3 & 1 \\
\hline Net Profit Ratio & $2.75 \%$ & $2.31 \%$ & $2.91 \%$ \\
\hline Rank & 2 & 3 & 1 \\
\hline Earnings Per Share & Rs.20.75 & Rs.7.8 & Rs.2.19 \\
\hline Rank & 1 & 2 & 3 \\
\hline Price Earning Ratio & 53.56 & 54.48 & 5.82 \\
\hline Rank & 2 & 1 & 3 \\
\hline Debt Equity Ratio & 0.0148 & 0.4 & 0.645 \\
\hline Rank & 3 & 1 & 2 \\
\hline Inventory Turnover Ratio & 164.38 & 2.7 & 2.24 \\
\hline Rank & 1 & 2 & 3 \\
\hline Debtors Turnover Ratio & 93.41 & 121.67 & 4.026 \\
\hline
\end{tabular}




\begin{tabular}{|l|l|l|l|}
\hline & & & \\
\hline Rank & 2 & 1 & 3 \\
\hline Assets Turnover Ratio & 0.85 & 0.4 & 0.39 \\
\hline Rank & 1 & 2 & 3 \\
\hline
\end{tabular}

Figure:1

\section{Analysis and interpretation of results:}

Analysis on the Liquidity Position:

The current ratio and Quick ratio of Provogue looks good compared to Shoppers Stop and Trent. It can be analysed that the liquidity position of Provogue is comparatively very good than the other two retail giants. Analysis on the Profitability Position:

The Gross Profit Ratio is 34\% for Provogue compared to 33\% of Trent and 32.70\% of Shoppers Stop. In the same way the net profit ratio is $2.91 \%$ compared to the other two firms.

The Earnings Per Share and Price Earning Ratio :

The Earnings Per share for Trent looks more attractive compared to that with Shoppers Stop and Provogue. The Price Earnings Ratio of Shoppers Stop is more profitable than the other two.

Analysis on the Capital Structure:

The capital structure and the leverage of shoppers Stop and Provogue looks pretty good over Trent.

Analysis on the Basis of Activity ratios:

Debtors Turnover ratio and Asset Turnover Ratios are categorized as the activity ratios.

Shoppers Stop is excellent in converting its debtors into sales during the year compared to Trent and Provogue.

Whereas Trent converts its assets faster into sales within a year.

Analysis on the overall Financial Position of the Company:

Provogue has very good liquidity position and stands first in these two ratios. It has good profitability postion also. But it lags behind in capital Structure and activity ratios. Whereas Trent has overall satisfactory financial position from the point of view of investors as well as from the management side. It is better for any investor to invest in this company to get good and consistent returns.

\section{Conclusion}

It can be concluded from the study that the investor or the general public interested in the investing in retail industry can invest in Trent if he or she is interested in the overall growth of the company. The decision of the Government to allow 51\% FDI in the retail sector also has the positive impact on Trent followed by Provogue and Shoppers Stop. The main limitation of the paper is that the data has been taken for the period of one financial year from the annual reports of all the three companies due to time constraints. The study can be applied to understand the impact of Government policy on the retail sector and also for the future research purpose by the researchers.

\section{References}

[1] Www.google.com
[2] http://www.bseindia.com/stock-share-price/trent-ltd/trent/500251/
[3] http://www.bseindia.com/stock-share-price/shoppers-stop-ltd/shoperstop/532638/
[4] http://www.bseindia.com/stock-share-price/provogue-(india)-ltd/provogue/532647/ 